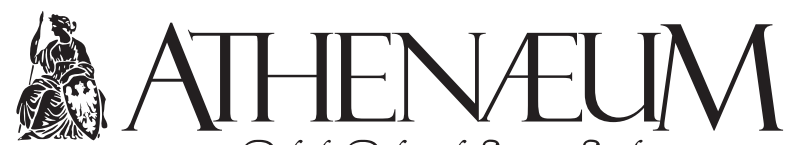

Polish Political Science Studies Polskie Studia Politologiczne

\title{
DO THE CELEBRITY POLITICS REALLY MATTER FOR HISPANIC VOTERS TODAY? THE COMPARISON OF BARACK OBAMA'S AND DONALD TRUMP'S PRESIDENTIAL CAMPAIGNS
}

\author{
CZY CELEBRYCI MOGĄ MIEĆ WPŁYW NA DECYZJE \\ LATYNOAMERYKAŃSKIEGO WYBORCY? \\ PORÓWNANIE PREZYDENCKICH KAMPANII \\ BARACKA OBAMY I DONALDA TRUMPA
}

Norbert Tomaszewski*

\begin{abstract}
The fast-growing Latino community in the United States became one of the most influential voting groups of this decade. The article shows how President Obama used the endorsement of Hispanic celebrities through viral videos and fundraisers to win among this community, while acknowledging and comparing this case to Donald Trump's presidential campaign in 2016, during which he could not count on the celebrities of Latin descent. The article tries to answer the question whether Hollywood can or cannot influence the ethnic voting groups and why this way of canvassing is only possible for the Democratic Party.
\end{abstract}

\begin{abstract}
ABSTRAKT
Latynoamerykanie przez zwiększanie swojej liczebności mają coraz większy wpływ na wyniki wyborów w Stanach Zjednoczonych. Artykuł pokazuje, w jaki sposób Barack Obama wykorzystał poparcie celebrytów latynoskiego pochodzenia, by zdobyć głosy tej grupy społecznej. Jednocześnie rezultat badania porównano z kampanią Donalda Trumpa z 2016 roku, będącego w zupełnie innej sytuacji. Czy Hollywood faktycznie jest w stanie wpłynąć na wynik wyborów przez manipulację zachowaniem wyborczym wybranych grup etnicznych? Czy taki sposób prowadzenia kampanii wyborczej to jedyna droga dla Partii Demokratycznej w XXI wieku? $\mathrm{Na}$ te oraz wiele innych pytań autor stara się odpowiedzieć, opierając się na teoriach marketingowych.
\end{abstract}

\footnotetext{
* University of Wrocław, Faculty of Social Sciences.
} 
Keywords: celebrity endorsement, Latino Americans, Hispanics, video, support, candidate, political marketing, presidential elections, Barack Obama, Donald Trump, Democratic Party, Republican Party, celebrity politics
Słowa kluczowe: celebrytyzacja polityki, Latynoamerykanie, kampania wyborcza, Partia Demokratyczna, Donald Trump, Barack Obama, zachowanie wyborcze

The world of celebrities always had strong links to the world of politics - over the years, the support of a celebrity towards a political option of their choice has proven that it could bring a mutual profit, benefiting the politician, who could be seen as "trendy" by the voter, but also generating media buzz for the artist. This correlation can be especially noticed in American politics, where famous people can be perceived as "modern gods" who are unreachable for the "average Joe". Such an approach in marketing case studies is rather young, but the influence of the celebrity politics has always been distinguishable and used by political actors to accomplish their aims. This situation, fuelled by the development of the new media and the pop-culturalization of the political discourse allows to shape a new kind of campaigning process, in which the style and the hype around the candidate play a more important role than the actual political program. It is important, however, to distinguish two models of celebrity politics that affect the campaigns - whereas these days charismatic leaders can establish themselves as celebrity politicians who gain popularity amongst voters by creating the hype, the aim of this chapter is to focus on the celebrities, who engage in political issues, but are not politicians per se. Their role is to gather their followers and fans and transfer their support to the one candidate that depicts their values and as a result is presented as "themselves" taking part in the election. With the political endorsement being the main topic, the theoretical framing of this article must not only focus on the politics, but also on the social and the cultural background of the relations between the voters and the celebrities. In my previous academic works, which focused on 2008 and 2016 presidential elections, the research targeted specific groups of celebrities and voters that had shared social background, which allowed them to feel the need for choosing a common candidate to fulfil their expectations. Such research can also be applied to analysis of the 2012 presidential elections, only with different social groups; whereas in 2008 Obama's campaigning staff focused on rappers and other Afro-American celebrities who were supposed to gather the Black vote, the fight for the presidential chair in 2012 concentrated on how to get the votes of the Latino community in the 
United States. In fact, the main purpose of this article is to analyse how Obama's campaign targeted this community through events and social media posts with the help of Latino celebrities and to analyse the evolution of this approach over four years which passed between the presidential elections in 2008 and 2012. The other focus of the work is the way in which Donald Trump approached the Latino community and whether he used the same tools to get their support. Lastly, the article describes the differences in handling of the campaign between the Democrats and the Republicans in terms of celebrity politics.

In the very beginning of the sociological and political thought related to the status of celebrity on the political scene, it is crucial to mention a German sociologist Leo Löwenthal, who in his 1944 essay called The Triumph of Mass Idols identified the main difference in how the biographies were written before and after the First World War. Whereas before the war, the idols of the masses were the "idols of production", people identified as the representatives of the ruling elites such as industry owners, high-ranked military officials or politicians, in $1930^{\text {s }}$ the biographies started focusing more on the "idols of consumption", who were lucky enough to become famous and entertain the ordinary people. The author suggests that when surveying the material on how the authors of the biographies evaluated their subjects, he found a lot of attention given to the way in which the writers both justified their heroes by means of superlatives, while still interpreting them in terms which could bring them as close as possible to the level of the average man (Löwenthal, 1944). According to Custen, Löwenthal explained how the morality of American citizens has changed and what lessons they would learn from the magazines; here biographies could prepare the average people to accept their place in the social structure, by letting them resign from the unreachable goals (Custen, 2001). The biographies helped the people connect with the world that was close, yet so far from their reach. The scientific approach to this trend in political marketing is rather young, but there are more and more publications that focus on this field. In their milestone publication, Celebrity Politics, West and Orman state: "Even though Americans tend not to trust politicians, they have great respect for and confidence in celebrities who enter the world of politics" (West \& Orman, 2003). This situation is recognised by the political strategists, since the voters nowadays make decisions based on the personalities of the candidates and since the popular culture and politics converge (Marland \& Lalancette, 2014). To fully describe this cohesion, one should first describe the role of the celebrity in the society and establish who could be counted as one. Rojek describes three types of the celebrity in the media: 
ascribed, achieved and attributed celebrity (Rojek, 2001). The first type is linked to a lineage; this has been a common situation in the past when the celebrity status could have been achieved by having the same bloodline as the royal family, or someone who has already achieved his status. The achieved celebrity, on the other hand, is a person that has successfully used their talents to establish their position in the media and become popular, such as sportsmen, musicians or the actors. Finally, there is a third type of the celebrity, attributed one that gathered the attention of the media due to the situation this person became involved in, in short, becoming a celebrity "created" by the media. Natalie Suleman, who gained the popularity by giving birth to octuplets, is the ideal example; what is more, her situation became such a hot topic in the mainstream media, she received a nickname "octomom", which she used to maintain her status (Rojek, 2001). Wheeler describes the power of the celebrities as the ability to influence their fans, fuelled by their audience's and media's investment in creating their "exceptional" role in the society (Wheeler, 2013). In his work, he recalls the academic works of Boykoff and Goodman, who determined the five factors defining the political status of the celebrity, namely celebrity performance, celebrity branding, celebrity artefacts, the political economy of the celebrity, and the response of the audience (Wheeler, 2013).

The celebrity performance focuses on the overall activity of the celebrity, both in their public and private life - by that one may mean the appearance that is caught by the media (paparazzi) which creates the image of the celebrity. This, by intruding their personal activities, lets the receiver of the information make an impression about the famous person and generates positive or negative emotions surrounding them. One must however remember that such perception may be controlled and used as a publicity stunt. The branding of the celebrity is linked to how this person is framed by the media - if the personality is appearing "cool" to the audience, it is easier for fans to be influenced by the celebrity. What is important, once the celebrity is "framed" as "hot", "shy", "flamboyant" or simply "funny", it is hard for them to change the way they are perceived. It is also linked to the celebrities' social or cultural background and their position in their field of interest - as Boykoff and Goodman mentioned, it is easier for Chris Martin from Coldplay to engage in environmental issues when he is playing soft-rock than if he played power metal (Boykoff, Goodman, \& Curtis, 2009). The celebrity artefacts are the images or characteristics linked to the celebrity which help them to become connected to the cause and make them easier to be associated by the media with the case they are dealing with. The political economy of the celebrity 
is the set of factors that make them valuable to the media, whereas the audience is the group that creates their value (Boykoff, Goodman, \& Curtis, 2009). The connection to the audience is the core of the relationship in the celebrity endorsement. As they represent the positions, the audiences may adapt them while forming their social identities. According to Marshall, “The celebrity's strength or power as a discourse on the individual is operationalised only in terms of power and position of the audience that has allowed it to circulate" (Marshall, 1997).

This academic perspective can be closely associated with the modern times, when standing for the social change can lead to the mass following and the celebrity obtaining the position as a symbol of change, just like what happened with Madonna and the LGBTQIA+ minorities (Gunter, 2014). Through establishing this connection, a fan may create a relationship with the celebrity, in which he may consider the similarities between them. This often leads to realizing the fact that both of the parties have similar goals and interests. If this is the case, the celebrities become vested with the power to speak publicly about the issues - their role in the society is being the voice of the people. Such interpretation can be supported by the case study of Obama's win in 2008, when the rappers, respected representatives of the black community, called for an action regarding the voter registration and the support for the senator from Illinois. The celebrity support could create the celebrity status of Obama, since he was eagerly using his social skills to appear to the people as "one of them". The theory formed by Erica Austin acknowledges that the external celebrities (which are not physically involved in the electioneering process) can attract the attention of the media and by that influence their followers into thinking positively about the political process, therefore having the potential to reach out to and mobilize the apathetic public (Austin et al., 2008). Taking these theories into consideration, Marland and Lalancette decided to distinguish two types of external celebrity support that is used to endorse the candidate: celebrity political endorsement publicists and fundraisers (2014). Most of the celebrities engaging in political campaigns belong to the first group. Using their position in the society they attract the media attention to forward this power to the campaign staff of the candidate they endorse. There is also a marketing value to the celebrity endorsement. Endorsers are seen as "dynamic with attractive and likeable qualities" (Erdogan, 1999). Companies transfer all the value from the celebrity to the product they are recommending, therefore making it easier for the buyer, who has a relationship with the endorser, to make the final decision leading to the purchase of the product. 
Celebrity endorsement also has its roots in cultural studies. It is worth to support this thesis with McCracken's "meaning transfer model". In his work, he states that the "cultural meaning is located in three places: the culturally constituted world; the consumer good; and the individual consumer, and moves in a trajectory at two points of transfer: world to good and good to individual" (McCracken, 1986). During this process, the cultural value of the celebrity allows the celebrity to be associated with the product, which later is endorsed by them and consumed by the consumer as the result of this action. With the "meaning" depending on its context, Hackley elaborates this thesis by defining the "meaning transfer" as "culturally embedded message codes" (Hackley, 1999). To understand the relationship between the politician, celebrity and the voter, it is needed to describe all three stages of this model. As it has already been established, the cultural background of the celebrity determines their position in the society and the show business. Stage 1 of the process focuses on establishing this position. According to a further work of McCracken, while anonymous models hired by the companies represent the social groups and target them, celebrities are "able to offer these meanings with special precision" (McCracken, 1989). With them being the more powerful media, they are able to attract the crowd and send the messages more powerfully. McCracken describes that celebrities draw the meanings from their roles in the media, as sportsmen or tough actors. With new dramatic role, the actor is set with the new pair of contexts in which he is seen (McCracken, 1989). The image the celebrity maintains during the endorsement process has already been established in its work. Since the choice of the celebrity is the part of a bigger, cautiously developed marketing plan, it is important to determine "which of the symbolic properties of the celebrity are in fact sought by the consumer" (McCracken, 1989). Taking this into the consideration, the candidate or the firm needs to set the ad that is operating on the same set of emotions as the ones that are linked to the celebrity. What is more, it is also important to minimalize the "meanings" that are not suitable for the product. For example in politics, a conservative actor, who is famous from his roles in action movies, can appeal to the voters that care about the gun-ownership laws, but if he is divorced, he will not appeal to the voters who put the family first - in this case it is better for the ad to avoid this issue. To achieve that, the advert must display the similarities between the celebrity and the product, so the consumer (voter) may take the last step in the meaning transfer process (McCracken, 1989). When the voter sees the similarity, he is ready to buy the product (candidate) that is a visualization of the endorsing one. At this point, the theory is brought into 
the third stage, in which the voter would equate him/herself with the candidate through the celebrity. Since the celebrity themselves is the "superconsumer" influencing the decision-making process, they play a new role - they are now seen as a role-model and inspiration, shaping the first stage of the consumer. If one would adjust this model to political marketing, it could become clear that in the last stage, the voter, by interacting with the candidate, engages in the canvassing process and feels the interaction with the celebrity, because of the values or background they are associating with at the very beginning. McCracken describes this correlation, by arguing, that "the constructed self makes the celebrity a kind of inspirational figure to the customer" (McCracken, 1989).

In 2012, Obama wanted to follow his 2008 success with the help of the celebrities. However, according to academics, they tend to engage less in the campaign process during second term elections. It can be established that there are three factors affecting this decision: first of all, the president is lacking the freshness effect - he did not have to canvass during the primaries, therefore his campaign is shorter and less entertaining. Secondly, there is an issue with the performance - the president has already made decisions that have affected his ratings; if celebrity supported him, then he or she could be held accountable for the actions of the politician - as a result, the ratings of the celebrity may fall. The third and last factor is the freshness of the endorsement - since the media and the fans already know that the celebrity has supported the politician during his fight for the first term, the announcement of the endorsement will lack any media buzz that would create hype for both the celebrity and the politician.

During 2008 elections Obama managed to attract the attention of two influential social groups: young people and the black community. He was the first hope of ethnic minorities, who, until 2008 elections, did not really feel they had a candidate that would care about their issues (Tomaszewski, 2015). These elections were different: Obama needed to focus on the undecided voters, who did not really engage with his PR movements. Moreover, in order to win, he had to turn to Latino community, which, according to experts, was supposed to play a crucial role in the elections. The plan was simple: the president had to once again use the celebrities to get the votes. His approval ratings among the Latino community kept falling because of the lack of any reforms focusing on the immigration law - even though in $2008,67 \%$ of the Latinos have chosen Obama, in 2011, 48\% of them supported the president (MacAskill, 2011).

Even though the elections were being held in autumn of 2012, Obama started to attract Latino celebrities in 2011. On October 24th, a first ever Latino 
fundraiser of big scale was held in the home of Antonio Banderas and Melanie Griffith (Meckler, 2011). Actors, along with Eva Longoria, who later became the most important celebrity to help Obama during the campaign, wanted to show their support and collect the money for the president-in-chief. While introducing the president, Longoria stated that Obama "speaks to Latino community, because he's a president of all Americans" (Gratereaux, 2011). In order to attract the ethnic voters, Obama, during his speech, mentioned that the immigration reform would be the most important task of his second term (Meckler, 2011). It is worth mentioning that not only Hollywood celebrities attended this fundraiser, with influential Latino politician, Mayor of Los Angeles Antonio Villaraigosa also being present at the event (Daunt, 2011). Another noteworthy fact is that the whole plan started even earlier - in June of 2011 Obama visited Florida and North Carolina, which gather a high percentage of Hispanic population. Florida was a key to the win, as the state is inhabited by Cuban community, which is rather Republican-oriented (Budoff Brown \& Thrush, 2011). After holding three fundraisers, Obama went to Puerto Rico, a good strategic move, since not only do Puerto Rican citizens usually vote for the Democrats, but they also tend to move to the mainland - according to the statistics, in Florida the Puerto Rican community grew by 76 percent in the past decade (Budoff Brown \& Thrush, 2011). As a result, more Hispanic voters registered in 2008 in Florida as the Democratic ones.

Obama knew that his tactics from 2008 may not be enough during these elections - he needed to underline the importance of Latino celebrities in his campaign staff. That is why he appointed Eva Longoria as one of the 35 cochairs of his campaign. What is more, six other nominees were Latino, which stands as proof of the campaign tactics that were assumed earlier - among other nominees one could acknowledge the presence of Antonio Villaraigosa, San Antonio's major Julian Castro, or Maria Elena Durazo, who at that time was a trade union official (Daunt, 2011). This move has officially expanded the role of the celebrity in the campaign process and acknowledged its importance as the link between the candidate and the voter. The main task of Longoria was to attract two important voting groups: Hispanic and women voters. The Women Vote 2012 Summit Tour was launched, a nationwide event happening in the most crucial swing states, aimed at women and Latino voters. It is interesting, however, how Longoria approached the subject of campaign rally, stating in the interview that she looks at her philanthropic and political activity as a citizen, not a celebrity (Turits, 2012). While planning to tackle issues important for the 
communities, such as equal payment for equal work, healthcare matters such as Planned Parenthood, organization that Obama's opponent Mitt Romney planned getting rid of, or fair education, Longoria admitted that her recognition as an actress is the key matter that allows her to reach the voters (Turits, 2012). Nevertheless, what mattered the most were the events during which celebrities could tackle issues with the community leaders to engage in the discussion on how to sort them out. This approach was covered in the media in the positive light, as it allowed the celebrities engage in such actions to show their "more human face", which could convince the voters that celebrities are just like them (Foley, 2012). During her speeches at the campaign events, Longoria told the crowd that "a woman should not vote Republican" (Levin, 2012). The tour was preceded by a clip uploaded on YouTube on April $26^{\text {th }}$ by an account BarackObama.com (2012), named Eva Longoria Shares Why She Supports President Obama. In this video, Longoria talks about her disabled sister Lisa and how she taught her how to overcome obstacles. Then she compares this situation to Obama's fight for equal rights of ethnic groups in the United States, mentioning his support for the small businesses in the Hispanic community and the reform of the immigration system. Two versions of the clip were uploaded on YouTube - one in English and one in Spanish. Few days earlier, a clip called President Obama Announces the 2012 Launch of Latinos for Obama, in which Obama announced the series of clips that would focus on Latino issues (2012). Another Latino celebrity that took part in this project was Rocsi Diaz, television personality of Honduran and Chilean descent. Her version of Latinos for Obama clip was uploaded on May 11th, 2012. Diaz, who became famous after appearing in MTV reality show Fear, was supposed to attract younger voters; in the clip she explains that she got involved in the elections, because Latino's are becoming the fastest-growing voting group in the United States and she feels that finally her community can be heard (BarackObama.com, 2012). Among other videos, one may also find a clip about nominating Justice Sonya Sotomayor to the Supreme Court. In the description it is stated that President Barack Obama would make sure that all of the children could one day become members of the Supreme Court if they wanted to, regardless of their background.

However Longoria was not the only one that was helping Obama to gain support among Latino community. Other recognizable celebrities also took part in his political campaign, although not at such important level. Most of them were mostly focused on organizing fundraisers for the candidate. In March 2012, the support came from the NFL superstar Victor Cruz, who co-hosted a fundraiser 
called "Family Game Night" with Michelle Obama, during which guests could check their bowling skills (Earle, 2012). It is worth mentioning that during the elections in 2012, Barack Obama no longer had to attend all of the fundraisers, since his wife has already established herself as a recognizable persona with wide support.

Hence, in May 2012, Obama attended two important Hollywood fundraisers - first of them, hosted by George Clooney, was attended by Salma Hayek; second of them, hosted by Ricky Martin, focused on LGBTQ+ issues. Martin was also playing a key role in attracting the voters, since he represented two communities that usually were Democratic voters: he was a Hispanic celebrity and he was representing the LGBTQ+ community. During the fundraiser, hosted not only by Martin himself, but also by Futuro Fund, a group that organized Latino fundraisers during Obama's campaign and the LGBT Leadership Council, the president promised to repeal the Defence of Marriage Act (Badash, 2012) and to focus on the DREAM Act, which would help some of the illegal immigrants matching the criteria to avoid being deported. As it has been analyzed from the social psychology point of research, his celebrity expertise, likeness and credibility were the factors that would determine the voters to approve his endorsement (Marland \& Lalancette, 2014). The event was also attended by Eva Longoria, which once again underlines the importance of her role during these elections. Martin supported Obama in Hispanic media - before the fundraiser, he said in the news program called Primer Impacto that the president should stay for the second term, citing Obama's fight for equal rights of Latino and LGBT community and setting milestones for the community, such as the appointment of Sonya Sotomayor as the first Hispanic Supreme Court Justice, as the main reasons of his endorsement (Bingham, 2012). Few days after the fundraiser, Martin posted a picture of him and Sotomayor on his Twitter feed (Badash, 2012). Additionally, also on Twitter, Martin endorsed Obama and applauded him for supporting the equal rights (Bingham, 2012). As a celebrity political endorser that was also a fundraiser, Martin's role was to target specific audiences to affect their voting behaviour, his endorsement being strictly focused on supporting specific policy (Marland \& Lalancette, 2014).

Marc Anthony was another celebrity that played a crucial role during Obama's presidential campaign. Musician appeared in a spot uploaded on YouTube called Marc Anthony: "The President Has Our Back", in which he explains that Latinos are the most influential voting group during presidential elections and that President Obama is on their side. His endorsement is targeted at the Hispanic 
community in the United States, as he says, "The President has our back, so it's time to let him know that we've got his" (BarackObama.com, 2012). The spot was recorded both in English and Spanish and was followed by another video of Marc Anthony opening Obama's office in Little Havana, Miami (VOXXINews, 2012). His support in the media was followed by a fundraising concert of Anthony in Miami Beach, Florida, focused on gaining funds for the campaign and getting the votes of the Latino community in this state (Bingham, 2012). Obama appeared at the event which was hosted by Enrique Santos, radio personality, who joked in English and Spanish to the attendees only to underline in the end of his speech that the president is going to make sure that Latino community will not get discriminated (Mazzei, 2012).

Before the 2012 Democratic National Convention, one important YouTube video was created for the Hispanic community. Cristina Saralegui, American journalist of Cuban descent, appeared in the endorsement spot made for Obama's campaign, in which she recounted her childhood and her parents moving to the United States to ensure a secure future for her. Because of that and hard work, she was able to succeed and pursue her dreams - by using her story, she explained that president Obama wants all of the children to achieve what they want, regardless of their race. Saralegui mentioned health and education policies as the key issues that Obama has taken care of (BarackObama.com, 2012). At the end of the video, journalist encourages the viewer to share her and their opinion with his neighbors and surrounding communities to make sure that the voice of Latino community is heard (BarackObama.com, 2012). Just like in the other case, the video was recorded both in English and Spanish to make sure that it would be fully understood by the widest possible target audience.

The Democratic National Convention took place between September $4^{\text {th }}$ and 6th, 2012; the event confirmed the already known tactic of the Democratic Party, trying to attract as many Latino viewers as possible. Antonio Villaraigosa, Mayor of Los Angeles, was appointed a Chairman of the Democratic National Convention. During the first day of the convention, the mayor of San Antonio, Julian Castro, took the stage to deliver the keynote speech, becoming the first Latino in the Democratic Party to do this job (Pilkington, 2012). Castro compared Romney's and Obama's policies, noting how the Hispanic community is politically divided and telling the crowd that only Obama is able to ensure that Latino issues would be taken care of (Pilkington, 2012). To prove his point, he mentioned Obamacare, which would allow 9 millions of uninsured Hispanic Americans to have access to medical care and the education changes that have made 150 
000 Hispanic students able to afford the education (Pilkington, 2012). It is also worth noting that his twin brother also delivered a speech that day - Joaquin Castro at that time was a member of the Texas House of Representatives. It is interesting how all of the Latino endorsers of Obama used one buzzword during their public appearances: opportunity. All of them stressed how important for them it was to receive an opportunity when they were younger which allowed them to reach their goals in order to show that President Obama wants to give the same opportunity to the Hispanic youth.

The third day of the convention once again stressed the importance of Latino votes with Marc Anthony singing the national anthem. Eva Longoria, as the most recognizable face of Obama's celebrity endorsement at the Democratic National Convention, delivered a speech in order to present her stance on economic issues. As she appeared on the stage, she told a story of two women: Eva Longoria back in her student years and Eva Longoria as an actress and a millionaire, declaring that as a student working in a burger restaurant she needed a tax break, whereas as an successful actress she is eager to pay taxes as a repayment to the community that once let her follow her dreams. Furthermore, she addressed her student years, when she had to take loans to pay the student debt, to prove a point and send the message to the voters that she knows the problems they are tackling from her own experience and is eager to help them (Foley, 2012). With this move, Longoria addressed issues that both young voters and Latino voters could identify with.

After the convention, the presidential campaign moved on to the next and final phase. This led to more adverts being created that targeted Latino community through the appearance of the celebrities of this background. The first one of the clips portrayed actor George Lopez, who encouraged viewers to register to vote. Lopez recalled his grandmother, who never missed the elections and always remembered to register. He also stated that it is up to him and other Latinos to get their community involved in the elections (BarackObama.com, 2012). Clip was recorded in English, but had Spanish subtitles. Another video was uploaded on October 15th, titled Obama Pride: Ricky Martin. It is interesting how Martin's role evolved during the campaign process - his video was created to attract the LGBTQ+ community and is not a part of the Latinos for Obama series. Victor Cruz, on the other hand, was still a celebrity endorser canvassing for the candidate as a part of Latinos for Obama. In his clip, Cruz compares the Election Day to a game day, when everyone is excited and focused (BarackObama. com, 2012). The last Latino celebrity that appeared in the campaign videos was 
Jennifer Lopez - her clips aimed at two target groups she represents: women and Latino voters. The clip Latinos for Obama displays Lopez advocating for Obama by first addressing her childhood years during which her family had to work hard to send her and her sister to school, which is later followed by listing the actions the president pursued to improve the social and economic situation of the Latino community (BarackObama.com, 2012). The spot also shows Latino volunteer campaign workers in their office and the door-to-door campaigns in Latin communities. The video was followed by Join Women for Obama 2012 clip, which depicts Lopez talking about growing up with her sisters, while on the right part of the spot the presidential couple is shown holding their daughters (BarackObama.com, 2012).

Not all of the campaign news in the media was favorable for the celebrities and the candidate. During Anna Wintour's fundraiser, Jennifer Lopez caught public eye wearing a red dress - since red is rather associated with the Republican Party, her choice was widely discussed within the gossip media (Mau, 2012). Also Eva Longoria had problems because of her activity within the media: she retweeted a post criticizing Mitt Romney, suggesting that minorities and women who would vote for the Republican candidate are stupid. After the backlash, she deleted the tweet and apologized to the voters stating that she respects all of the Americans (Constantini, 2012). Longoria attended all of the most important rallies until the very end of the campaign, eagerly appearing with Michelle Obama and Marc Anthony, who joined them in Miami (JustJared.com, 2012).

When Obama won against Mitt Romney, Hispanic celebrities reacted with joy - Eva Longoria tweeted “We did it!!! Obama re-elected!!!!! Yes!! Yes We Can!”, while America Ferrera congratulated everyone who took part in the elections, stating that this is what makes this country great (Celebuzz, 2012). According to the Pew Hispanic Center's statistics, Obama won the Latino vote by a large margin as he received $71 \%$ of their votes with Romney receiving 27\% (Lopez \& Taylor, 2012). The president managed to overcome the main obstacle and win in Florida, as he carried Hispanic vote $60 \%$ to $39 \%$ - this is a result of the growing non-Cuban population in the central part of the state, especially Puerto Rican (Lopez \& Taylor, 2012). What is interesting is that Obama won against Romney among the Cuban community with the result of $49 \%$ comparing to Romney's 47\%. According to Florida exit polls, 34\% of Hispanic voters were of Cuban descent. The report also tackled the most important issues for the Hispanic voters, as $59 \%$ of them stated that economy was the main issue (Lopez \& Taylor, 2012). Regarding the demographics during the 2012 elections, Obama 
was supported by $76 \%$ of Latino women and $65 \%$ of men. He was very popular among Latino youth and college graduates, and it is interesting how popular Obama was with the voters whose total family income was below $\$ 50,000$ - he received $82 \%$ of their votes. Compare that to the Latino voters whose family had higher income than $\$ 50,000$, of this group only $59 \%$ voted for Obama (Romney received 39\% of the votes; Lopez \& Taylor, 2012). Another research, created by Thom File, shows that the voting rate among Latinos has decreased in comparison to previous presidential elections, comparing $49,9 \%$ result in 2008 to $48 \%$ in 2012 (File, 2012). This, however, may be a result of the bigger number of Latinos being eligible to vote - while in 2008 around 19,537,000 of them could vote during the elections, in 2012, 23,329,000 of Hispanics were able to vote (Lopez \& Gonzalez-Barrera, 2013).

The political issues of Latino community became one of the hottest topics of the 2016 presidential campaign, however, the Republican candidate, Donald Trump, focused on attacking the Hispanic voters by promising changes to the immigration law and building a border wall between the United States and Mexico. Even though his campaign did not seem to attract this group of voters, he managed to gain the support of few public personas who represented this community. The most famous celebrity of Latin descent is Tito Ortiz, a former mixed-martial arts artist. Ortiz, who attended a Trump rally in Anaheim, later uploaded a post on Instagram comparing Donald Trump to Ronald Reagan, explaining that he cares about the safe borders and the troops - that is why he does not believe Hillary Clinton and why he is supporting the wall on the border (Cagewriter, 2016). Another important endorsement came from the Latino leaders who have penned a letter that expressed the support for Trump during the presidential elections. In a letter of support, which was signed by fourteen conservative Hispanic leaders, the signatories have explained that the fear of the terrorist attacks in the United States and unclear immigration policies of Hillary Clinton led to them deciding to support Donald Trump, even though they did not support him during the primaries. Among the leaders, one could find Alfonso Aguilar, who was a head of the Latino Partnership for Conservative Principles, or Massey Villarreal, who was a former president of the Hispanic Chamber of Commerce (McLaughlin, 2016). What is interesting is the fact that this support was withdrawn just a few weeks later; Aguilar told the media that the group felt that they needed to give a second chance to Trump after he had secured the Republican nomination, but his speech in Mexico City and Phoenix, which announced a rather harsh take on the immigration 
policies, left the Hispanic conservatives disillusioned about his political program (Tesfaye, 2016). In Phoenix, Trump announced that Mexicans will have to pay for the wall on the border. At the same time, at the beginning of September, for the same reason, Jacob Monty, who was a member of Trump's National Hispanic Advisory Council, resigned from the board (Tesfaye, 2016). Monty, who is a lawyer, stated that he provided a plan that would strengthen the border security and allow the hard-working Latinos to stay in the country, but the plan was rejected by the candidate (Lee, 2016). As Trump decided to resign from softening his rhetorics, his support among the influential Hispanic voters began to decrease. Last but not least, Trump received the support from his two ex-rivals, with whom he was fighting for the Republican nomination - Marco Rubio and Ted Cruz. None of the politicians, however, was eager to back Trump's candidacy - Rubio has endorsed him in July 2016, after strongly criticizing him during the campaign. Rubio called for the unity of the Republican Party against the Democratic candidate, Hillary Clinton, and publicly endorsed Trump in a short video. Ted Cruz has expressed his support even later - his decision was announced through Facebook when on September 23rd, 2016, he posted that after months of consideration he decided to endorse Trump. According to the sources, Mike Pence, who was Trump's vice presidential nominee, encouraged Cruz to back Trump, even though politicians did not have a good relationship (Schleifer, Borger, \& Bash, 2016).

Having analyzed these endorsements, one may acknowledge that none of the A-list celebrities of Hispanic descent have backed Trump during the presidential campaign. He was only supported by Latino activists who were conservative and even while having such a small group of endorsers, he managed to lose some of their support. Many experts, however, were shocked when the results of the election came in, since Trump earned $28 \%$ of Latino votes, which was a better result compared to Mitt Romney's 27\% in 2012. According to Ilan Stavans, conservative Latino voters relied on the promises of job formation (for instance, in Arizona), while disregarding the threats of the wall (Stavans, 2018). What is more, Hispanic voters who supported Trump did not really care about the polls or his stance on Mexico and immigration - they believed that his speeches are taken out of context and exaggerated in the media. One can acknowledge that Hispanic conservatives are people who are satisfied with their social status and do not believe that immigration politics could affect them. What is more, they are eager to support the harsh politics against illegal immigrants in order to distance themselves from the less fortunate members of their ethnic group. 
There is no doubt that the Latino community is becoming one of the most influential voting groups in the country, as the results of the 2012 presidential elections in the United States show. The key sociodemographic data is the one that shows that Latinos are much younger than Americans (27 compared to 37 years old; Garcia Bedolla, 2015). Fully understanding this, an assumption can be made that Latino community is and will be an attractive target group for the campaigning politicians. During 2012 presidential elections, president Obama's campaign staff used celebrities in order to reach out to the voters who would not be interested in politics, or would feel left behind in in the country of their residence. As the celebrities nowadays play the role of citizens that share similar social background with the voters they are targeting, they may appear as superhumans who were able to succeed; one should keep in mind the specifics of United States, where success plays an important role in the community. The main buzzwords of the campaign that were used to attract the Hispanic voters were "opportunity" and "chance"; exactly what the celebrities were given once, which allowed them to achieve their dreams, now being the time for the younger generation to experience the same. While using their history, they could "sell" president Obama to the voter as the man that would be able to help them in this process, through creating encouraging policies. It is interesting that Obama followed the pattern from the 2008 elections with his use of celebrity endorsements, but this time the tactic was used more consciously, as seen in the appointment of Eva Longoria as a campaign ambassador. Because of that, one may recognize a special role reserved for the celebrity during the campaign, which can be defined as a "key political endorser". Such person can create buzz for the candidate in the media and through hosting fundraisers, but may also, by using his or her charisma skills, tour the country along with the candidate and his campaign staff in order to meet with the voters personally and tackle the presented political issues along with the experts. Longoria's role during 2012 presidential elections was very important and no celebrity from the 2008 presidential elections came close to this level of significance for any of the candidates.

Another difference in how the celebrity endorsement was handled in the rivalry of 2008 and 2012 can be found in the tactics of Barack Obama. His moves during the second elections were more mature and more calculated, he no longer was an underdog that appeared fresh to the celebrities; he was now a president who has cooperated with Hollywood stars for a long time, met with them at the White House and worked with them on fixing the policies. This can be seen in how he approached the Latino community - the campaign with the celebrities 
was carefully planned, as his campaign staff has chosen Hispanic endorsers from Puerto Rican and Cuban descent to attract specific groups of voters from this community.

The study confirms that Democratic voters tend to select their candidate when he or she is supported by the celebrity they trust. This allows the party to continue its voter tactics, but on one condition that should be introduced - the celebrity needs to represent the same background or values as the voter. After 2008 elections, the Democratic Party knew how to approach the voters and how to select specific celebrities to target them. It is worth noting that still, celebrity politics are not the most important part of the campaign strategy, but may help in a particular situation when the candidates fight for the support of one social group. Celebrities will always be eager to support the politician they trust $-90 \%$ of Hollywood stars represent liberal or progressive values, therefore the Democratic candidate can select his favorite endorsers and create tasks for them, since it would generate buzz for both of the interested parties.

Taking all of those features into consideration, while comparing the presidential election results in 2012 and 2016, one may ask if the celebrity politics are actually time-worthy. In fact, the 2016 elections have proven that without the support from famous endorsers, Trump was able to get an even better result within Hispanic voters than Mitt Romney. The key to understanding Trump's success lies in his persona - since he has become a political A-list celebrity, he was able to generate a buzz around him. It should be acknowledged that Democratic voters care about the endorsements, whereas Republican voters recognize that their politics do not seem "cool" to liberal stars. Therefore it can be established that Donald Trump did not require celebrity support, because the voters treat him as a celebrity himself. The history shows that Republican voters think about the celebrities as the establishment, therefore they do not tend to switch their political choices when they see endorsements. The case of the 2016 elections shows that the minority voters no longer tend to be attracted by the celebrities from their communities, it can even be established that nowadays, White, Hispanic or Afro-American voters present similar political behaviour, which can be an interesting challenge for the campaign staffs in the United States in the future. 


\section{REFERENCES:}

Badash, D. (2012). Look: Ricky Martin Meets and Tweets Sonia Sotomayor. Retrieved from: http://www.thenewcivilrightsmovement.com/look-ricky-martin-meets-andtweets-sonia-sotomayor/news/2012/05/21/39862.

Bingham, A. (2012). Pop Star Ricky Martin Courts Latino, Gay Supporters for President Obama. Retrieved from: http://abcnews.go.com/Politics/OTUS/ricky-martinendorses-president-obama/story?id=16343760.

Boykoff, M., Goodman, M., \& Curtis, I. (2009). Cultural Politics of Climate Change: Interactions in the Spaces of Everyday. Environment, Politics and Development Working Paper Series 11. London: King's College London.

Budoff Brown, C., \& Thrush, G. (2011). Obama's Quest for Hispanic Votes. Retrieved from: https://www.politico.com/story/2011/06/obamas-quest-for-hispanicvotes- 056787.

Celebuzz (2012). Barack Obama Wins 2012 Election, Celebrities React. Retrieved from: http://www.celebuzz.com/2012-11-07/barack-obama-wins-2012-electioncelebrities-react.

Constantini, C. (2012). Eva Longoria Apologizes for Controversial Retweet. Retrieved from: https://abcnews.go.com/ABC_Univision/eva-longoria-apologizes-controversial-retweet/story?id=17510004.

Daunt, T. (2011). Melanie Griffith Holding Obama Fundraiser at Their Home. Retrieved from: https://www.hollywoodreporter.com/news/antonio-banderas-melaniegriffith-barack-obama-eva-longoria-247627.

Earle, G. (2012). Victor Cruz to Co-host Obama Fundraiser at Chelsea Piers. New York Post. Retrieved from: https://nypost.com/2012/03/10/victor-cruz-to-co-hostobama-fundraiser-at-chelsea-piers/.

Erdogan, B.Z. (1999). Celebrity Endorsement: A Literature Review. Journal of Marketing Management, 15(4), 291-314. DOI: 10.1362/026725799784870379.

Garcia Bedolla, L. (2015). Latino Politics. New Jersey: John Wiley \& Sons.

Gratereaux, A.J. (2011). Eva Longoria, Antonio Banderas Take on Latino Fundraiser for Barack Obama. Retrieved from: http://www.foxnews.com/entertainment/2011/10/ 25/eva-longoria-antonio-banderas-take-on-latino-fundraiser-for-barack-obama. html.

Gunter, B. (2014). Celebrity Capital: Assessing the Value of Fame. New York: Bloomsbury Publishing USA.

Hackley, C. (2005). Advertising and Promotion: Communicating Brands. New York: SAGE.

Hale, A. (2016). MMA Legend Tito Ortiz Endorses Donald Trump, Chants "Build That Wall" at Rally. Retrieved from: https://sports.yahoo.com/blogs/mma-cagewriter/ tito-ortiz-endorses-donald-trump--chants--build-that-wall--at-rally-023154145mma.html. 
JustJared.com (2012). Eva Longoria \& Michelle Obama Campaign for Barack Obama. Retrieved from: http://www.justjared.com/2012/11/03/eva-longoria-michelleobama-campaign-for-barack-obama.

Khorana, S. (2013). Crossover Cinema: Cross-Cultural Film from Production to Reception. New York: Routledge.

Lee, K. (2016). Several of Donald Trump's Latino Advisors Resign After His Immigration Speech. Los Angeles Times. Retrieved from: http://www.latimes.com/nation/ politics/trailguide/la-na-trailguide-updates-1472752828-htmlstory.html.

Levin, S. (2012). Photos: Eva Longoria, Valerie Jarrett Come to Colorado to Promote Obama 2012. Retrieved from: http://www.westword.com/news/photos-evalongoria-valerie-jarrett-come-to-colorado-to-promote-obama-2012-5847088.

Lopez, M.H., \& Taylor, P. (2012). Latino Voters in the 2012 Election. Washington, DC: Pew Hispanic Center.

Lowenthal, L. (1944). The Triumph of Mass Idols: Essay. New York: Routledge.

MacAskill, E. (2011). Obama Courts Hispanic Vote on Fundraising Tour of the West. The Guardian. Retrieved from: https:/www.theguardian.com/world/2011/oct/25/ obama-hispanic-voters-banderas-longoria.

Marland, A., \& Lalancette, M. (2014). Access Hollywood: Celebrity Endorsements in American Politics. In: J. Lees-Marshment, B.M. Conley, \& K. Cosgrove (eds.), Political Marketing in the United States (pp. 130-147). New York: Routledge.

Mau, D. (2012). Should Jennifer Lopez Not Have Worn Red to Anna Wintour's Obama Dinner in Paris? Retrieved from: https://fashionista.com/2012/10/should-jenniferlopez-not-have-worn-red-to-anna-wintours-obama-dinner-in-paris.

Mazzei, P. (2012). Obama Rakes in Campaign Cash at Miami Beach Fundraiser with Marc Anthony. Miami Herald. Retrieved from: http://www.miamiherald.com/news/ politics-government/article1940846.html.

McCracken, G. (1986). Culture and Consumption: A Theoretical Account of the Structure and Movement of the Cultural Meaning of Consumer Goods. Journal of Consumer Research, 13(1), 71-84. DOI: 10.1086/209048.

McCracken, G. (1989). Who Is the Celebrity Endorser? Cultural Foundations of the Endorsement Process. Journal of Consumer Research, 16(3), 310-321. DOI: $10.1086 / 209217$.

McLaughlin, S. (2016). Latino Leaders Switch Gears, Announce Plans to Endorse Donald Trump. The Washington Times. Retrieved from: https://www.washingtontimes. com/news/2016/jul/18/donald-trump-garner-support-latino-leaders.

Obama, B. (2012). Retrieved from: https://www.youtube.com/user/BarackObamadotcom/videos.

Pilkington, E. (2012). Julian Castro: Meet the Democrats' Rising Star. The Guardian. Retrieved from: https://www.theguardian.com/world/2012/sep/04/julian-castrodnc-speech-democrats.

Rojek, C. (2001). Celebrity. London: Reaktion Books. 
Schleifer, T., Borger, G., \& Bash, D. (2016). Ted Cruz Endorses Donald Trump. Retrieved from: http://edition.cnn.com/2016/09/23/politics/ted-cruz-endorses-donaldtrump/index.html.

Stavans, I. (2018). Latinos in the United States: What Everyone Needs to Know. Oxford: Oxford University Press.

Tesfaye, S. (2016). Top Latino Trump Supporters Revoke Their Endorsements Following Hardline Immigration Speech. Retrieved from: https://www.salon.com/2016/09/01/ top-latino-trump-supporters-revoke-their-endorsements-following-hardlineimmigration-speech.

Tomaszewski, N. (2017). The Impact of the Internet 2.0 on the Voting Behaviour in the United States of America: The Analysis of the 2016 Presidential Primaries. Annales Universitatis Mariae Curie-Skłodowska, Sectio K - Politologia, 24(1), 97-114. DOI: 10.17951/k.2017.24.1.97.

Turits, M. (2012). 5 Qs with Eva Longoria at the Obama Women Vote 2012 Summit Tour Launch. Retrieved from: www.glamour.com/story/5-qs-with-eva-longoria-at-the. West, D., \& Orman, J. (2003). Celebrity Politics. New Jersey: Prentice Hall.

Wheeler, M. (2013). Celebrity Politics: Image and Identity in Contemporary Political Communications. Cambridge: Polity Press. 